\title{
Awareness Level of Emotional Intelligence among Customer Relation Executives in Tourism Companies in Muscat Region
}

\author{
Syed Aulia \\ Research Scholar - Faculty of Management Department, Pacific Academy of Higher Education and \\ Research University, Udaipur
}

\begin{abstract}
Emotional intelligence, which in general is referred as personal and social intelligence, is important and plays a significant role in maintaining good interpersonal relationships and social-interactions, especially with customer's in-case of tourism industry. This paper attempts to provide an understanding of awareness level of emotional intelligence among customer relation executives in tourism companies in Muscat region. The present paper will give an insight how different aspects of emotional intelligence will have a positive impact while dealing with prospective customers (tourist) and maintaining a long term relationship. The study explores the level of awareness of emotional intelligence among the respondents in tourism companies.
\end{abstract}

Keywords: Emotional intelligence, customer relation executives, tourism, tourist, Muscat.

\section{INTRODUCTION}

Tourism Industry is one of the largest global industry, and the tourism market is growing. According to the World Tourism Organization (WTO), the global tourism market will triple in size by 2020 . Tourism benefits local economies substantially by increasing foreign exchange earnings, creating employment and investment opportunities, increasing government revenues, developing a country's image, and supporting all sectors of the economy as well as local communities. (Middleton, 2009)

Briedenhann, J., \&Wickens, E. (2004) Tourism for any country is a very critical factor. It introduces a country to the world. It showcases a country on the world map \& promotes it on a larger scale. It helps in economic develop of a country.

For Oman, tourism came into focus in mid 1990"s when the Oman's economy was taking a long term development strategy for its development. This was divided into four main dimensions namely Macro economic framework, Human resource, Economic diversification, Development of private sector. Oman has all the elements of a focused-type of tourism in the areas of nature and adventurous activities.

Definition of Tourism : The World Tourism Organization defines tourists as people who "travel to and stay in places outside their usual environment for not more than one consecutive year for leisure, business and other purposes not related to the exercise of an activity remunerated from within the place visited".

Sally K, Nicola S. Schutte, (2005) when dealing with customers, organizations need to understand the emotional requirement and guide them in a way so as to attain satisfaction. Emotional intelligence comes into picture specially when dealing with angry customers and can make the difference and influence a customer to come back to buy the services again. Customer Engagement boosts organization's revenue margin and ROI.

Goleman .D(1995), the expert and author of many books on emotional intelligence including Working with Emotional Intelligence has addressed its relevance to business in his book, as per him "How customers feel when they interact with an employee determines how they feel about the company itself. In a psychological sense, the 'company' as experienced by the customer is these interactions. Loyalty is lost or strengthened in every interaction between a company and its customers."

Kernbach \& Schutte (2005) Customers want a friendly and helping people around, implementation of emotional intelligence among employees will bring in a new dimension to customer satisfaction and 
hence help in achieving brand loyalty among customers. On the contrary lack of people skills can arise for a number of reasons, ranging from shyness, and mood swing in an employee or disrespect for the job.

Salovey P, Mayer J, Caruso D (2004) One of the most important skills for employees is the ability to listen and understand the customer. Emotional intelligence gives individuals the ability to pick up on the emotions of others and anticipate their feelings. As a result, they are able to listen and act in a way that leads to a favorable emotional outcome, benefiting both parties.

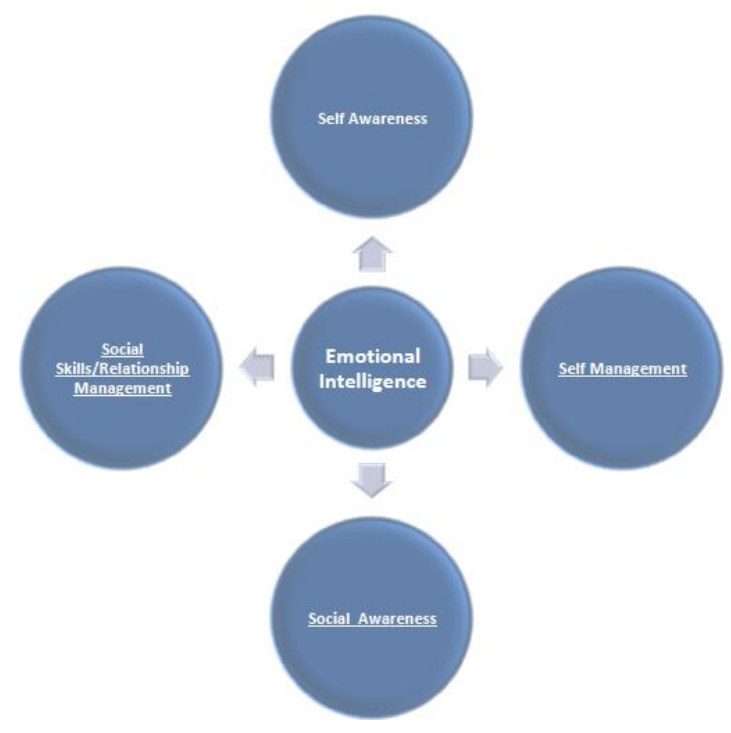

Frame Work of Research

Four elements of emotional intelligence (Goleman .D 1998):

Self Awareness: One can learn to understand the language of emotions while dealing with people in everyday life. Being little more sensitive to slight variations between emotions can be helpful in achieving the emotional bound. For example to identify a growing emotion over time or recognize slight variations in emotions.

Self Management: In an action-packed life that we all are living in, having control on ones emotions go a long way. Various activities such as thinking, reacting and problem solving become simple while you are emotionally intelligent. Such a person can surely benefit and outshine in the task at hand.

Social Awareness: Emotions helps an individual identify not only his own emotions but also emotions of other people. Apart from reading human beings perceiving emotions also implies to images, tone of voice, artistic work of art. Perceiving emotions represents a characteristic of emotional intelligence thus enabling an individual to process emotional information.

Relationship Building: It's the ability to adjust emotions in ourselves and also in the other person. By doing this you can achieve the desired objective and feel satisfied within a given situation. Emotional intelligent person can achieve better score in his day to day responsibilities and also will be develop good rapport and relationship with people around..

\section{Problem Statement}

Many researchers interested in studying the concept of emotional intelligence in the areas of work and education, they also emphasized that it has great successes in various fields of life. That emotional intelligence contributes $80 \%$ of success in life, so the researcher believes that the acquisition of employee's emotional intelligence skills to help them to cope with the pressures during work because they face many kinds of pressure, including the family, psychological, social and financial. Hence, this study is being conducted to determine the awareness level of emotional intelligence while performing their task at work.

The current study is trying to answer the probable question:

1. What is the level emotional intelligence of employee?

2. What is the role of emotional intelligence to the employee? 
Awareness Level of Emotional Intelligence among Customer Relation Executives in Tourism Companies in Muscat Region

3. How emotional intelligence among employee's leads to their being content with themselves and job?

\section{Objectives of Study}

1. Understanding the awareness level of emotional intelligence among the customer relation executives

2. To know the overall emotional intelligence of among the customer relation executives.

3. How to have the advantage of the emotional intelligence skills in the development and management of self and organization.

\section{RESEARCH METHODOLOGY}

\subsection{Data Used}

Primary data: collected through structured questionnaire using the likert's scale

Secondary data: collected through books, magazines, research journals, internet, newspapers etc.

Sample size: 50 respondents

Sample unit: Customer relation executives of selected tourism companies in Muscat Oman.

Data collected through convenience sampling method (non-probability method)

\subsection{Limitations of the Study}

During the survey although the respondents were very co-operative \& extended their full support, yet there were following limitations associates with my study which I would like to mention:

1) Due to the busy schedule of an organization it was not possible to capture the responses of the managerial staff.

2) The approach is based on the questionnaire and results are drawn on their inputs given.

3) Considering a limited sample, the results are approximates only.

4) One of the most important limitations is the participation of the limited respondents.

\section{Data Analysis}

\section{Descriptive Statistics}

\begin{tabular}{|l|l|l|l|l|l|}
\hline Particulars & $\mathrm{N}$ & Mean & Std. Deviation & Minimum & Maximum \\
\hline Gender & 50 & 1.4400 & .50143 & 1.00 & 2.00 \\
\hline Nationality & 50 & 1.6800 & .47121 & 1.00 & 2.00 \\
\hline Work_exp & 50 & 2.2200 & .88733 & 1.00 & 4.00 \\
\hline
\end{tabular}

\section{Frequencies}

\begin{tabular}{|l|l|l|l|}
\hline Gender & Observed N & Expected N & Residual \\
\hline Males & 28 & 25.0 & 3.0 \\
\hline females & 22 & 25.0 & -3.0 \\
\hline Total & 50 & & \\
\hline \multicolumn{2}{|l}{} \\
\hline
\end{tabular}

\begin{tabular}{|l|l|l|l|}
\hline Nationality & Observed N & Expected N & Residual \\
\hline Omani & 16 & 25.0 & -9.0 \\
\hline non-omani & 34 & 25.0 & 9.0 \\
\hline Total & 50 & & \\
\hline
\end{tabular}

\begin{tabular}{|l|l|l|l|}
\hline Work Experience & Observed N & Expected N & Residual \\
\hline less than 5 years & 12 & 12.5 & -.5 \\
\hline $6-10$ years & 18 & 12.5 & 5.5 \\
\hline $11-15$ years & 17 & 12.5 & 4.5 \\
\hline more than 15 years & 3 & 12.5 & -9.5 \\
\hline Total & 50 & & \\
\hline
\end{tabular}


Syed Aulia

Chi-Square Test Values of Gender, Nationality and Work-experience

\begin{tabular}{|l|l|l|l|}
\hline & Gender & Nationality & Work_exp \\
\hline Chi-square & $.720^{\mathrm{a}}$ & $6.480^{\mathrm{a}}$ & $11.280^{\mathrm{b}}$ \\
\hline Df & 1 & 1 & 3 \\
\hline Asymp. Sig. & .396 & .011 & .010 \\
\hline a. 0 cells (.0\%) have expected frequencies less than 5. The minimum expected cell frequency is 25.0. \\
\hline b. 0 cells (.0\%) have expected frequencies less than 5. The minimum expected cell frequency is 12.5. \\
\hline
\end{tabular}

Descriptive Analysis of the given parameters (Gender, Nationality, Work experience)

\begin{tabular}{|c|c|c|c|c|}
\hline \multicolumn{3}{|l|}{ Particulars } & Statistic & Std. Error \\
\hline \multirow[t]{13}{*}{ Gender } & \multicolumn{2}{|l|}{ Mean } & 1.4400 & .07091 \\
\hline & \multirow{2}{*}{$\begin{array}{l}\text { 95\% Confidence Interval for } \\
\text { Mean }\end{array}$} & Lower Bound & 1.2975 & \\
\hline & & Upper Bound & 1.5825 & \\
\hline & \multicolumn{2}{|l|}{ 5\% Trimmed Mean } & 1.4333 & \\
\hline & \multicolumn{2}{|l|}{ Median } & 1.0000 & \\
\hline & \multicolumn{2}{|l|}{ Variance } & .251 & \\
\hline & \multicolumn{2}{|l|}{ Std. Deviation } & .50143 & \\
\hline & \multicolumn{2}{|l|}{ Minimum } & 1.00 & \\
\hline & \multicolumn{2}{|l|}{ Maximum } & 2.00 & \\
\hline & \multicolumn{2}{|l|}{ Range } & 1.00 & \\
\hline & \multicolumn{2}{|l|}{ Inter quartile Range } & 1.00 & \\
\hline & \multicolumn{2}{|l|}{ Skewness } & .249 & .337 \\
\hline & \multicolumn{2}{|l|}{ Kurtosis } & -2.020 & .662 \\
\hline \multirow[t]{13}{*}{ Nationality } & \multicolumn{2}{|l|}{ Mean } & 1.6800 & .06664 \\
\hline & \multirow{2}{*}{$\begin{array}{l}95 \% \text { Confidence Interval for } \\
\text { Mean }\end{array}$} & Lower Bound & 1.5461 & \\
\hline & & Upper Bound & 1.8139 & \\
\hline & \multicolumn{2}{|l|}{$5 \%$ Trimmed Mean } & 1.7000 & \\
\hline & \multicolumn{2}{|l|}{ Median } & 2.0000 & \\
\hline & \multicolumn{2}{|l|}{ Variance } & .222 & \\
\hline & \multicolumn{2}{|l|}{ Std. Deviation } & .47121 & \\
\hline & \multicolumn{2}{|l|}{ Minimum } & 1.00 & \\
\hline & \multicolumn{2}{|l|}{ Maximum } & 2.00 & \\
\hline & \multicolumn{2}{|l|}{ Range } & 1.00 & \\
\hline & \multicolumn{2}{|l|}{ Interquartile Range } & 1.00 & \\
\hline & \multicolumn{2}{|l|}{ Skewness } & -.796 & .337 \\
\hline & \multicolumn{2}{|l|}{ Kurtosis } & -1.425 & .662 \\
\hline Work-Exp & Mean & & 2.2200 & .12549 \\
\hline & $95 \%$ Confidence Interval for & Lower Bound & 1.9678 & \\
\hline & Mean & Upper Bound & 2.4722 & \\
\hline & $5 \%$ Trimmed Mean & & 2.1889 & \\
\hline & Median & & 2.0000 & \\
\hline & Variance & & .787 & \\
\hline & Std. Deviation & & .88733 & \\
\hline & Minimum & & 1.00 & \\
\hline & Maximum & & 4.00 & \\
\hline & Range & & 3.00 & \\
\hline & Interquartile Range & & 1.25 & \\
\hline & Skewness & & .091 & .337 \\
\hline & Kurtosis & & -.847 & .662 \\
\hline
\end{tabular}

\section{Descriptive Statistical Analysis of the given parameters}

\begin{tabular}{|c|c|c|c|}
\hline & Mean & $\begin{array}{l}\text { Std. } \\
\text { Deviation }\end{array}$ & Analysis N \\
\hline $\begin{array}{l}\text { 9) When I am in a positive mood, I am able to come up with new } \\
\text { ideas. }\end{array}$ & 2.7800 & .95383 & 50 \\
\hline 10) I have control over my emotions. & 2.7800 & .76372 & 50 \\
\hline $\begin{array}{l}\text { 11) I motivate myself by imagining a good outcome to a task I take } \\
\text { on }\end{array}$ & 2.9000 & .93131 & 50 \\
\hline 12) When I am faced with a challenge, I will not give up until I & 2.7600 & .74396 & 50 \\
\hline
\end{tabular}


Awareness Level of Emotional Intelligence among Customer Relation Executives in Tourism Companies in Muscat Region

\begin{tabular}{|c|c|c|c|}
\hline achieve. & & & \\
\hline 13) I know what other people are feeling just by looking at them. & 2.7800 & .76372 & 50 \\
\hline 1) I am aware of my emotions as I experience them. & 3.0200 & .97917 & 50 \\
\hline 2) I like to share my emotions with others. & 2.7800 & .78999 & 50 \\
\hline 3) I am aware of the non-verbal messages i send to others & 2.6200 & .56749 & 50 \\
\hline 4) I know when to speak about my personal problems to others & 2.4800 & .83885 & 50 \\
\hline $\begin{array}{l}\text { 5) I find it hard to understand the non-verbal messages of other } \\
\text { people. }\end{array}$ & 2.7200 & .75701 & 50 \\
\hline 6) I present myself in a way that makes a good impression on others. & 2.2400 & .51745 & 50 \\
\hline 7) When I am in a positive mood, solving problems is easy for me. & 2.5600 & .57711 & 50 \\
\hline $\begin{array}{l}\text { 8) By looking at their facial expressions, I recognize the emotions } \\
\text { people are experiencing }\end{array}$ & 2.4000 & .78246 & 50 \\
\hline
\end{tabular}

\section{FINDINGS OF THE STUDY}

$100 \%$ of employees are aware of their emotions when they experience them and they like to share their emotions with others. $88 \%$ agree with the fact that they know when to speak about their personal problems to others, $12 \%$ are neutral about the same.

$88 \%$ agreed that when they are in a positive mood solving problems is easy for them and $12 \%$ showed neutral response and $70 \%$ of employees agreed that they present themselves in a way that makes a good impression on others \& $30 \%$ disagreed to it.

$78 \%$ of employees 'agreed' that they find it hard to understand the non-verbal messages of other employees, $22 \%$ showed a 'neutral' response about the same; $62 \%$ of employees agree that they are aware of the non-verbal messages they send to others, $22 \%$ are neutral about the same while $16 \%$ are unaware of the non-verbal messages they send to others.

$22 \%$ of employees agreed that they can recognize the emotions people are experiencing by looking at their facial expressions, $30 \%$ are neutral and $48 \%$ employees disagree about the same. $20 \%$ of employees say that they have control over their emotions, $26 \%$ have a neutral response while $54 \%$ say that they do not have control over their emotions all the time at workplace.

$100 \%$ of employees agreed that when in a positive mood they are able to come up with new ideas and $80 \%$ of employees 'agreed' that imagining a good outcome to a task motivate them, $20 \%$ showed a 'neutral' response;

$70 \%$ of employees 'agreed' that they will not give up until they achieve a given challenge at workplace, $20 \%$ showed a 'neutral' response; while $10 \%$ disagree with the same. $20 \%$ of employees agree with the fact that they can predict what other people are feeling just by looking at them, $26 \%$ showed a neutral response while $54 \%$ employees disagreed with the same.

Over all the study reveals that the respondents are very much aware about the emotional intelligence concept.

\section{Conclusion}

Although Emotional intelligence (EI) being the fairly new concept, All the responded agreed that they are aware of their emotions when they experience them and they like to share their emotions with others. Majority of respondents agrees that they know when to speak about their personal problems to others. Most of the respondents feel that it's easy to solve the problem with positive frame of mind. The element of self awareness and self management of emotional intelligence (EI/EQ) are very much satisfactory in terms of their outcome while dealing with others.

However majority of the respondents had a problem with the non verbal communication with their colleagues, customers, and tourist and did not able to get the message in the right frame. Moreover it was difficult to control/ hold the emotions while dealing with prospective customers, which suggests that the element of social awareness and relationship building of emotional intelligence (EI/EQ) is little lacking. In this regard it will be appropriate to provide relevant training pertaining to emotional intelligence (EI/EQ) which will provide them the knowledge required to become more sensitive towards others and also in understanding the emotions of others in a systematic manner. When a person becomes emotionally intelligent he/ she will be more in control of situations while dealing with others. 


\section{RECOMMENDATIONS / SUGGESTIONS}

In any organization people makes the difference and the successful professionals (executives) are the one who understands their client's emotions and feelings at first place. It is the people (customers) who are the key differentiators in the success of tourism business for any organization. Hence investment to understand and solve their difficulties / problems of customers will make any organization very successful.

External training may be imparted to make more awareness about emotional intelligence concept among the executives in tourism business with an emphasis on social awareness and relationship building / empathy.

Employees (Customer care executives) suggestions may be considered while sending them for behavioral related training programs, especially new incumbent staff members need to be given more of such training programs.

\section{Directions for Future Research}

The study includes awareness of emotional intelligence among the executive staff in different travel and tourism companies across in Muscat region. The study is confined to Muscat region only. There is a great scope to extent the study to other regions of Oman as well and for better inferences this study may be used as a secondary source for the studies. It can be used as a base study for further research on other services sectors like air line staff, insurance hospitals and education sector.

\section{BIBLIOGRAPHY}

Briedenhann, J., \&Wickens, E. (2004). Tourism routes as a tool for the economic development of rural areas - vibrant hope or impossible dream? Tourism Management, 25(1), 74-79.

Goleman D. London: Bloomsbury; 1995. Emotional Intelligence: Working with Emotional Intelligence.

Goleman, D. 1998. Working with emotional intelligence. London: Bloomsbury.

Kernbach \& Schutte (2005), "The impact of service provider emotional intelligence on customer satisfaction", Journal Of Marketing, 19(7).

Middleton, V. T., Morgan, M., Fyall, A., \& Ranchhod, A. (2009). Marketing in Travel and Tourism . Elsevier, 121-127.

Sally Kernbach, Nicola S. Schutte, (2005) "The impact of service provider emotional intelligence on customer satisfaction", Journal of Services Marketing, Vol. 19 Issue 7.

Salovey P, Mayer J, Caruso D. Emotional intelligence: Theory, findings, and implications. Psychology Inc.2004.

\section{Websites}

www.hoteliermiddleeast.com

http://www.mot.gov.om

www.omantourism.gov.om

www.omanworldtourism.com

http://v5.books.elsevier.com 